\title{
Spatial reading: evaluative frameworks and the making of literary authority
}

\section{Günter Leypoldt ${ }^{1}$}

Published online: 28 July 2020

(C) The Author(s) 2020

\begin{abstract}
This essay uses Charles Taylor's theory of evaluative frameworks to solve a problem that has challenged literary theory and historiography for some time: how do we square the tension between the private uses and the public authority of reading? Taylor's notion of strong value brings out literature's often-overlooked similarities with religious-moral or civil-sacred domains, while his concept of weak value helps us to understand more mundane moods of purpose-rational reading. Combining the concept of evaluative frameworks with a socio-institutional account of literary authority, this essay sketches an alternative history of reading, with a focus on the shifting authority of "spatial reading" (defined as attention to formal and intertextual depth). Looking at developments from the 1780 s to the present, I will show how the distinction between spatial and flat reading emerges in the eighteenth century, is transformed by the modernist institutionalization of high- and middlebrow notions of spatial form, and continues to provoke tensions between the civil sphere and the literary-artistic field (as the recent scandal around Peter Handke's Nobel Prize attests).
\end{abstract}

Keywords Reading · Evaluative frameworks · Literary authority · Civil sphere · History of literary institutions

\section{Introduction}

As readers we participate in two value systems at the same time, one rooted in the everyday, the other in a sort of moral economy. In the everyday, readers are consumers, free to choose whatever suits their purpose, impatient with normative opinions about literary quality or schoolroom canonicity. In a moral economy, the pleasure of reading can feel like a higher pleasure when what we read has the authority of "serious" or "great" art. "Authority" in this case rests on public "economies of prestige"

Günter Leypoldt

Leypoldt@as.uni-heidelberg.de

1 Heidelberg Center for American Studies, American Literature, University of Heidelberg,

Heidelberg, Germany 
(English 2005) that orient our sense of how a novel is placed in the more or less consecrated regions of cultural space. Of course, it is possible to consume James Joyce's Ulysses (a highly canonical museum object) for mindless pleasure, or to admire Dan Brown's The Da Vinci Code (a blockbuster with no critical acclaim) as a serious thing of beauty. But such uses depend on personal sensibilities and biographies of reading (one needs to be a bit bookish to find Ulysses entertaining, and disconnected from authorized taste to admire Brown's literary form). By contrast, our sense of how an artifact is placed in the culture-the feeling that Ulysses or the Nobel Prize look down at us as if from a higher position, while The Da Vinci Code or Fifty Shades of Grey look up from a supermarket of entertainment commodities-rests on public hierarchies that transcend our individual situation.

This tension between the private uses and the public authority of reading is a challenge for a literary scholarship that wants to frame literary value with a single logic. In the next three sections, I respectively (i) outline the problems of single-logic approaches in literary theory and criticism today (my aim is to propose an alternative model that draws from Charles Taylor's phenomenology of evaluative frameworks); (ii) argue that Taylor's distinction between strong and weak frameworks helps us to gain a more coherent picture of readerly judgment; and (iii) flesh out my argument with a socio-institutional account of literary authority, suggesting that strong-valued reading can recall the experience of moral or religious "higher goods" (Taylor) or a "civil sacred" (Alexander). In the remainder of this essay, I put weak and strong evaluative frameworks in historical perspective, complicating the familiar rise-and-fall narratives of literary history. This alternative history of reading will focus on the shifting authority of "spatial reading" (for formal and intertextual depth), from the 1780s to the present.

\section{Single-logic concepts of value: literary events vs. readerly uses}

The quest for single-logic concepts of value has divided literary criticism into two theoretical camps: one grounds authority in singular literary events ("the work in context"), the other in popular uses of texts.

Event-centered literary criticism tends toward a normative outlook that locates literary value in a text-context structure, often with a scientistic sense that a literary artifact's worth is distinct from its "social lives" (Appadurai 1986). The emphasis on structure is obvious in formalist debates about what can count as aesthetic brilliance or stylistic innovation, but it also shapes the now more common "anti-formalist" enterprise of ideology critique that frames literary value in terms of political-moral progressiveness. While formalist accounts revolve around the "inner logic" of literary-aesthetic compositions, ideology critique often treats texts as symptoms of social structure - aesthetic manifestations of a "political unconscious," in Fredric Jameson's (1981) influential terms. ${ }^{1}$ In both approaches, audiences and consecrating institutions play only secondary roles: A work like Ulysses seems to grow out of the "field" of

\footnotetext{
1 The emphasis on form - or textual structure - reaches from Kantian philosophies of art to the new criticism ("practical criticism" in England, "explication de texte" in France, "textimmanente Literaturkritik" in Germany) and the highly theoretical schools of Russian Formalism, structuralism, and Derridean "deconstruction," all of which can be described as "textualist" (Rorty 1982, chap. 8). An emphasis on
} 
culture and society, like a strange plant to be categorized and diagnosed by the observing scholar-botanist. While formalists seek to describe the function of a textual whole, anti-formalist ideology-critics look for the artifact's "cultural work," treating the text as an expressive source that-if put on the couch and probed for its suppressed depths - reveals "the way a culture thinks about itself" (Tompkins 1985, p. xi). To the degree that a work's value is linked to morally and politically prestigious issues (social justice, race relations, gender inequality, neoliberalism, animal rights, climate catastrophe), the ethnography of reading seems less important, to be relegated to mere "auxiliary sciences" (Hilfswissenschaften) such as reception history or literary sociology.

The other side of the literary-theory landscape focuses on literature as a popular practice and hopes to ground literary excellence in the demos rather than in the textual or ideological structure. The emphasis on popular practice produced a widespread "rise of modern literature" narrative that portrays literary history since 1700 as a process of increasing commodification and democratic liberation. After the sharp eighteenth-century increase in leisure reading, the story goes, "the centre of gravity of the reading public" shifted away from the learned elites, toward less educated readers, who preferred "an easier form of literary entertainment" (Watt [1957] 2000, p. 48). The idea of a global swerve toward popular audiences produced well-known visions of doom ("culture industry"), but also notions of a "fortunate fall" that frame the marketplace as a healthy corrective to self-indulgent elitism. The latter view first emerged in the 1830 s and 1840 s, when a growing class of freelance journalist-novelists (like Charles Dickens or W.M. Thackeray) mapped entrepreneurial concepts of literary authorship to a Whig history of political liberation. ${ }^{2}$ With reference to only a handful of exceptional authors who managed to combine critical success with significant sales (Scott, Dickens, or Zola), the literary marketplace was rebranded as a democratic institution that emancipated readers from a corrupt aristocracy and an interfering church and state. ${ }^{3}$

\footnotetext{
Footnote 1 (continued)

structure also shapes some schools of recent narratology and text-analytical data-mining. By contrast, Jameson's emphasis on literature's "political unconscious" recalls an intellectual history of Hegelian, Marxist, and Freudian "critique" that shifts the focus of interpretation from the structure of the text to the structure of determining contexts of which the text is thought to be an aesthetic manifestation. Best and Marcus (2009, pp. 3-6) speak of "symptomatic" criticism. See Felski (2015) on the routinization and Aubry (2018) on the displaced formalism in symptomatic criticism. For an account of "critical sociology" as reducing the arts to determining causes, see Hennion (2015).

2 On Whig history, see Collini (2019, chap. 1).

3 Whereas the standard eighteenth-century phrase "author by profession" had been more or less a slur (referring to Grub Street hackery or pamphleteer journalism [Griffin 2014, pp. 143-4]), the nineteenthcentury liberation narrative made commercial success a sign of real authority, distinguishing serious professionals from posturing gentleman-amateurs, and legitimating popular taste against elitist gatekeeping. As Émile Zola claimed in 1880, the expanding marketplace took the authority to "judge and award success" away from the "little coteries" of salons and academies and returned it to "the great mass of readers" ([1879] 1893, pp. 191, 193). Victorian Whig historians refer to Dr. Johnson's 1755 letter to Chesterton as an iconic moment for authorial emancipation. Thomas B. Macaulay's 1830 review of John Wilson Croker's edition of James Boswell's Life of Samuel Johnson for the Edinburgh Review is a good example of this.
} 
The Whig narrative ignores the increasing relevance of market-sheltered institutions (as I will argue in greater detail in the section on "Strong value as public feeling"). Here I want to stress that the discourse of reader emancipation resonated well with twentieth-century cultural studies movements, encouraging programmatic appraisals of popular culture that reject literary canons as pseudo-sacred ersatz. religions. Janice Radway, for example, positioned her reappraisal of "middlebrow" readers against an academic obsession with "a few sacralized books as objects to be revered or fetishized" (1997, p. 360). In an autobiographical reminiscence about her graduate school experience, Radway framed her own professional coming of age as an ordeal of cultural self-colonialization: an ivory-towered elite compelled her "to keep my voracious taste for bestsellers, mysteries, cookbooks and popular nature books a secret" from "everyone, including the more cultured and educated self I was trying to become" (2). Radway's anecdote shows how well the democratic concept of literary authority, which compares readers to voters in representative democracies, aligns with "expressive identity" models that regard literary works as speech acts by which cultural identities represent themselves. Identitarian expressivism allows us to redescribe hierarchical scales of value (X is better than $\mathrm{Y}$ ) in terms of difference in equality (X and $\mathrm{Y}$ are both great, on their own terms). Accordingly, Radway suggests that the choice between difficult modernist novels and light middlebrow genre fiction represents different but equally dignified "reading cultures" rather than higher and lower levels of excellence.

If we view texts as expressions of cultural identities, to be sure, canon-building becomes as absurd as the ranking of cultures in nineteenth-century armchair anthropology ("Few would dispute," Edward Tylor said in Primitive Culture, "that the following races are arranged rightly in order of culture:-Australian, Tahitian, Aztec, Chinese, Italian" [(1871) 1903, vol. 1, p. 27]). In the spirit of the Herderian relativism in early-twentieth-century cultural anthropology (Kuper 1999, p. 66) and cultural pluralism (Sollors 1986, p. 97), the literary canon debates of the 1970s and 1980s on American campuses drew from an ethic of "high-cultural pluralism" (McGurl 2009) that legitimizes ethno-racial writers as representatives of subnational identities. In this context, critics justified the "canon wars" of the 1970s and 1980s as a "politics of recognition" on behalf of excluded identities. The identitarian ethic of equal dignity cultivates a hostility to non-representative consecrating institutions that gels well with the delivery-of-satisfaction model of reading. If readers view themselves as shoppers free to suit their personal needs, why should their consumption habits be micromanaged by the normative claims of experts in elitist gatekeeping institutions?

\section{Beyond a single logic: Taylor's theory of strong and weak frameworks}

Both the equal-recognition and the consumer-satisfaction model of reading underestimate the degree to which literary experience can have an investment in a "higher good," similar to the experience of religion and morality. In Charles Taylor's broad definition of moral experience (one that cuts across moral-aesthetic and religious-secular divides), people orient themselves toward notions of 
higher good with the help of identity-defining "frameworks" of "strong evaluation" (1989, pp. 19-20). Strong frameworks "involve discriminations of right or wrong, better or worse, higher or lower" whose validity does not follow from "our own desires, inclinations, or choices, but rather stand independent of these and offer standards by which these can be judged" (p. 4). Thus: "To think, feel, judge within a framework is to function with the sense that some action, or mode of life, or mode of feeling is incomparably higher than the others which are more readily available to us" (p. 19). Taylor uses the spatial qualifier in generic terms that can be expressed with a range of different distinctions. "One form of life may be seen as fuller, another way of feeling and acting as purer, a mode of feeling or living as deeper, a style of life more admirable, a given demand as making an absolute claim against merely relative ones, and so on" (p. 20). Historically, distinguishing absolute from relative claims can be traced to the Axial Age, the period around the middle of the first millennium BC in which the rise of scholarly clerical elites coincided with a new opposition between the transcendent and the mundane (Eisenstadt 1982; Bellah and Joas 2012). "Transcendent" in this context can have a traditional religious sense- "a going beyond the human world and the cosmos"-but it can also apply to secular investments in a "standpoint from which the existing order in the cosmos or the society can be criticized or denounced" (Taylor 2011, p. 367). In theory, we habitually stress the deconstructability and hence normative irrelevance of absolute standpoints. In lived practice, however, standpoints are performative, that is, their relevance hinges on the affective intensity with which we feel "placed" in relation to a perceived "higher good." Taylor's point is that in the performative sense all cultures have strong-valued frameworks, even though these can be hard to recognize, as they are often located at the "background" (1989, p. 21) of our actions, as tacit knowledge or a practical sense rather than a fully articulated account. While modern social imaginaries always pose a plurality of frameworks - we can be "moved" by many higher goods, and torn between incommensurable ones-they tend to come to us "ranked" (p. 62) in an order of importance. At the top of our hierarchical order of strong-value frameworks lies the sphere of "hypergoods," that is, "higher-order goods" that not only strike us as "incomparably more important" than other goods of strong value but also as providing "the standpoint from which these must be weighed, judged, decided about" (p. 63).

Not every evaluative activity, to be sure, is of identity-defining intensity. There is a large domain of practice-the domain of "weak valuation" (Taylor 1985, p. 16) - in which the ranking of frameworks seems less urgent. People can be passionate about their favorite ice-cream flavor, but they would hardly start a culture war about such issues. Weak valuation makes hierarchical scales feel less imperative, allowing us to be more tolerant of disagreement ["I like strawberry and you vanilla," no use arguing about taste (Taylor 2011, p. 297)]. The more we move toward hypergood-related issues-fair trade, abortion, Brexit, human rights violations, or the like - the harder it becomes to adopt a relativist tolerance of dissent. Strong values are "sacralized" (Joas 2013) in the sense that we experience them with an intensity that immunizes us against the skeptical questions of rational or scientific argument. In the flow of experience, of course, weak and 
strong values tend to be bundled together, as when your favorite food, say, seems all the more enjoyable if it also embodies the moral authority of "fair trade." The analytical distinction remains significant, however. Whereas weak frameworks concern our everyday desires, strong ones are linked to the hierarchical imaginaries with which we classify our desires into higher or lower kinds- "more and less fulfilling, more and less refined, profound and superficial, noble and base" (Taylor 1985, p. 16; Joas 2000, pp. 129-31). Whereas weak values emerge in the situated rationalities of our personal lifeworld, strong ones seem to transcend our subjective aims. We experience them as appealing to us from the outside of our habitual selves and purposive routines [as in Max Weber's "Außeralltäglichkeit," something "outside (Außen)" "everdayness (Alltäglichkeit)" (1972, p. 140)].

Taylor's account complicates the single-logic concepts of value that dominate literary scholarship. Literary experience, too, involves these two essentially different intensities of judgment. The most obvious case of weak valuation is light literary entertainment. Reading for no better reason than pleasurable distraction can turn any literary text into something like a pleasant meal or a warm bath, to be consumed, enjoyed and afterwards perhaps forgotten. As weak evaluators, we subordinate our reading to everyday needs and thus (in Richard Rorty's apt phrase) "beat the text into a shape which will serve [our] own purpose" (1982, p. 151). If we have a "politics" or "ethics" of reading at all, it mostly concerns the weighing of pragmatic outcomes (did we enjoy the experience, have we chosen well among conflicting goods, or has our consumption practice prevented other perhaps more desirable activities?). In the mode of strong valuation, by contrast, the reading experience implies identitydefining contact with an absolute standpoint against which the "excellence" of literary options is to be judged. Strong-valued works have a way of looking down upon us as from a height. "You have to change your life," Rilke hears a Greek sculpture give out to him in the Paris Louvre, suggesting he should make a greater effort to lift himself up to a more elevated region within the cultural landscape ([1908] 1995, p. 67). This sense of "being spoken to from above" (Sloterdijk 2013, pp. 22-23) can make us feel, in Paul Valéry's phrase, "that we are in some profound sense transforming ourselves" to "become the person whose sensibility is capable" of hearing and comprehending the higher call ([1937] 2016, p. 965; see Rosa 2019, p. 284).

Single-logic theories of literary value fail to grasp the potential simultaneity of these essentially different evaluative repertoires, as readers shift between weaker and stronger frameworks without necessarily subordinating one to the other. Formalist approaches treat weak-valued consumption as an embarrassment: "bad reading" for "paraliterary" ends, in Merve Emre's (2017) paraphrase. Cultural studies sensibilities, by contrast, tend to drop the idea of bad reading altogether because the representative democracy and delivery-of-satisfaction frames bristle in the face of practice-transcendent notions of higher good. Both approaches collapse the distinction between weak and strong frameworks. Ideology critics claim that since "everything is political," the most innocent pleasures will reveal strong-valued investments ("you think you like vampire fiction for its entertainment value, but let me tell you why you really find such stories appealing"). Cultural studies defenses of popular taste often explain away weak valuation by universalizing strong-valued uses of leisure (such as individual self-realization, subcultural emancipation, or the transfiguration 
of the ordinary, etc.). And many linguistic-turn-inspired post-1960s literary-theory programs propose the relativity of all literary-artistic value in a way that universalizes weak-valued reading. ${ }^{4}$

Taylor's theory of literary value, by contrast, requires us to be more attentive to the phenomenological range of readerly uses. It is possible to binge-read texts with the same purpose-rational forgetfulness with which we consume a slice of toast. In this mood, we can perfectly ignore "deeper" textual ideologies or the pull of authorized canonicity, and leave any engagements with "higher goods" to professional "virtuosi" or aspirational schoolroom readers. But it is also possible-in a different mood - to become susceptible to the "calling" of strong value, just as we can suddenly feel the moral attraction of farmers markets while shopping for food. Whether or not we are susceptible to the pull of hypergoods seems to be a question of "attunement" (Highmore 2017; Felski 2020). If we approach the system of literary prizes as weak evaluators (consumers seeking to satisfy personal needs), we are likely to treat literary awards like popular "rankings" or "rating systems" (see Spoerhase 2018)—Lucien Karpik speaks of "trust devices [dispositifs de confiance]" or "judgment devices [dispositifs de jugement]" (2010, p. 44) that help us to reduce the opacity of the marketplace (Leypoldt 2017, pp 57-58). In the mode of weak valuation, the most prestigious literary prize can have a similarly mundane function as the now ubiquitous "people-who-bought-this-also-looked-at-that" algorithms: Whether we prefer to consult the Booker, the Nebula, or the Nobel then hinges on our calculative trust in concrete outcomes. This everyday use fuels economistic views of the prize system as complicit with commercial book markets (see Brouillette 2015). But once we attune ourselves to identity-defining hypergoods, prizes begin to resemble peer review systems that transcend everyday rationalities by inspiring relational (rather than calculative) trust in higher goods. For strong evaluators, the prize system no longer merely designates desirable content but also points toward higher and lower regions within a more hierarchical cultural landscape. In this case, the system of prizes acquires a vertical tension: some prizes (the Nobel, the Booker, the Goncourt) strike us as closer to the higher moral life of the culture than others (e.g., the Nebula).

\section{Strong value as public feeling: consecration, canonization}

The "higher moral life of the culture" can sound odd in our pluralist age, and science fiction fans routinely insist that-for them-the Nebula Award is infinitely more valuable than the Nobel or any other consecrating affordances propped up by "the so-called authorities." In theory, of course, every reader could attune themselves to strictly personal hypergoods. This would make the perception of a literary-artistic sacred as subjective as the perception of the religious sacred in the individualist religion Robert Bellah ([1985] 2007) described as "Sheilaism" (drawn from "Sheila Larson," an interviewee who said she was religious but only according to a "faith"

\footnotetext{
4 See, for example, Herrnstein-Smith's (1988) pragmatist relativism, and Guillory's (1993) critique.
} 
based on "[j]ust my own little voice"). Bellah was troubled by Sheilaism because he thought it suggested "the logical possibility of over 220 million American religions, one for each of us" (p. 221). His worry rested on the fact that a religious framework based on the beliefs of a single person can no longer supply an identity-defining moral hypergood: The presence of 220 million religions in the US would downgrade their differences to the level of ice-cream flavors. But Larson's seeker-spirituality (Wuthnow 1998) combines an individualist theology with widely shared non-theistic strong values. Her sense of "something beyond" her mundane self (Ammerman 2013, p. 269) draws its force from a "civil sacred" produced in the civil sphere (Alexander 2019, p. 108) rather than a clerical-religious field..$^{5}$ The civil sacred revolves around democratic ideals of tolerance and solidarity (in Larson's words, "I think [God] would want us to take care of each other" [Bellah et al. (1985) 2007, p. 221]), but this does not make it any less hierarchical. What counts as a higher good in civil sphere discourse, according to Alexander (2006, pp. 57-59), emerges with the help of strong frameworks that distinguish "civil" from "uncivil" lifeforms along the lines of higher or lower human decency, moral integrity, social justice, solidarity, and so on.

Alexander's account of the civil sacred shows, I think, that since strong frameworks emerge in response to public structures of feeling, the idea of an individualized hypergood is a contradiction in terms. Disagreements about what counts as human decency or social justice tend to affect the public square, and often evolve into "hot-button issues" that can drive culture wars (Hartman 2015). Functioning liberal democracies thus require a shared canon of strong-valued assumptions about what counts as civil behavior. I want to argue that literary-artistic canons invoke a similar public connection with higher goods to the canons of the civil sacred. While the consecrated objects of the civil sacred (the Lincoln Memorial, say, or Notre Dame Cathedral) and the literary-artistic canon (from Shakespeare's Hamlet to prize-winning fiction) require different strong frameworks, they produce similar kinds of "vertical resonance" (Rosa 2019, p. 284). ${ }^{6}$

The family resemblances between civil-sacred and literary-artistic canons can be obscured by a reductionist "rise of modern literature" narrative that tells the story of literary professionalization in "low-professional" terms, as a historical shift from

\footnotetext{
5 As Woodhead and Heelas point out, "in reality, people like Sheila are institutionalized in that they share much the same spiritual culture or 'church' (sustained by books, films, like-minded friends, and so on)" (2000, p. 354). Viewing Sheilaism as a sign of religious decline owes much to the "de-intensificiation theory" of secularization (Partridge 2006, p. 8), which has not aged well in the sociology of religion (see Taylor 2007, Connolly 2000, Berger 2014).

6 Common objections draw from the longstanding division of intellectual spheres (as in Kant's three "Critiques") that ties "aesthetic autonomy" to the formal-artistic registers of genre (universalizing microlevel differences between symbolic and conceptual formal logics). Within the flow of readerly practice, I would argue, the question of a work's genre (whether it leans toward conceptual argument, fictional narrative, or poetic symbolism and the like) becomes secondary to whether it suits our everyday purposes or brings us toward a higher good. It seems more helpful to define aesthetic autonomy in socio-institutional terms, as hinging not on formal logics but the performative authority of "peer-oriented" consecrating institutions in defining which formal logics constitute a higher good (on institutional autonomy, see Sapiro 2016 and 2019b).
} 
patronage-based amateurs to commercial "authors by trade," in which weak-valued reading largely wins the day. More recently this has encouraged reports that serious reading is becoming a "residual" practice (Brouillette 2019a, p. 453)—“"an object of cultural consumption for dwindling and aging publics" (Franssen and Kuipers 2015, p. 292; see Brouillette 2019b, p. 18). The trouble with such declension stories, however, is the misconception that weak and strong values compete on the same turf. In fact, since the mid-1700s the literary field saw two shifts of gravity: The "reading revolution" that between 1750 and 1850 displaced difficult epic poetry with a bingereadable "easier form of literary entertainment" (Watt [1957] 2000, p. 48) did of course happen, but it mostly concerned weak-valued leisure habits, when "extensive reading" for entertainment or leisure replaced other traditional middleclass ways of killing time. A second shift, however, regarding strong frameworks, tipped the balance in the opposite direction: the extending artistic-intellectual networks between 1800 and 1950 strengthened literature's peer-oriented consecrating institutions. The challenge, for a cultural sociology of literary value, is to recognize the complex relation between statistical numbers and public authority (Leypoldt 2016). With the rise of large-scale leisure reading, peer-oriented taste became a minority position that carried disproportionate weight in shaping the public sphere.

While weak-valued leisure reading defined the rules of rapidly commercializing markets, peer-oriented consecration consolidated a region within cultural space I want to call (following Richard Helgerson [1983]) the "laureate position" in the literaryartistic system. ${ }^{7}$ The defining trait of laureate writers-from Spenser to contemporary prize-winners - is a "high-professional" ethos that distinguishes serious authors from both literary amateurs and commercial writers. The high-professional ethos evolved in the early-modern "liberal" or "learned professions" (the ministry, law, medicine), stipulating that private gain be subordinated to a sense of "higher calling," obligation to a public good, and authorization by independent peer review. This means that financial transactions must correspond to people's sense of a "good match" in Viviana Zelizer's sense, a form of exchange that sustains the moral-cultural attachments between professionals and the social whole, at the same time as it "gets the economic work of the relationship done" (2011, p. 153). According to the high-professional sense of a "good match," professionals deserve a great deal of money for their services, but excessive attention to the market value of their skills turns physicians into quacks, lawyers into confidence men, soldiers into mercenaries, and writers into hacks. Thus the low-professional emphasis simply on how much money markets will "pay" for "professional writers" (Brouillette 2019a, p. 454) conflates weak- and strong-valued literary labor. Writers of high ambition have always found the relationship between literary authority

\footnotetext{
7 As Helgerson points out, in Anglophone literature the laurate position emerged with Edmund Spenser, the first author who publicly embodied the social identity of a poet as a serious career for intellectuals who wished to serve a higher good through literature rather than in the church, the state, or the military. Helgerson's point is that when Spenser graduated from Cambridge in 1576, all poets were of gentle birth, with a humanist education that encouraged them to write verse in their youth, but in adulthood they were expected to move on to more virtuous civic action (like Sir Philip Sidney, who thought of himself as a career diplomat merely dabbling in poetry, and never published his now famous work during his lifetime).
} 
and economic success rather tense, even in the nineteenth century, the period often identified with literature's financial independence. ${ }^{8}$ This remains true for today's literary culture (Sapiro 2019a), when the most prestigious writers survive on a mixture of academic or cultural patronage and the secondary proceeds that follow critical success. It is not yet clear how the measurable decline of leisure reading in recent years (which leaves some literary pastimes with "aging publics") will affect the shape and authority of laureate-oriented literary production.

Understanding these socio-institutional complexities requires a historical perspective. In what follows, I want to flesh out the shifting binaries of good and bad reading with a sketch of relevant historical developments, focalized through a phenomenology of weak- and strong-valued reading. With the eighteenth-century rise of leisure reading, I argue, bad reading came to be viewed as a neglect of "reflective" or "spatial" form. First, I will provide a working definition of "spatial reading," then discuss how it emerged in late-eighteenth-century debates about "reading addiction," how it changed when the modernist avant-gardization of the literary field produced different kinds of elite readers, and changed again with the massive decrease of leisure reading after the 1950s. The final section ("Spatial reading in the civil sphere") shows how different regimes of spatial reading have shaped the competing authority claims of civil and literary-artistic spheres, from the nineteenth century to Handke's Nobel controversy.

\section{Spatial reading}

Professional literary critics can be ambivalent about literary entertainment because their reading pleasures revolve around habits of "scholarly reading" as both a source of delight and serious work. John Guillory suggests that scholarly reading is more "vigilant" than lay reading because it partakes in a shared activity oriented toward peer review-based notions of higher good. Whereas lay readers are allowed to binge their texts as superficially as they wish, and then forget everything, scholarly reading cannot "begin and end in the pleasure of consumption" but must give rise to "sustained reflection” (2000, p. 31).

Reflectiveness involves what I want to call (following Joseph Frank) spatial reading, a mode of attention that treats a text like a multidimensional structure, a space rather than a temporal narrative. Spatial reading, in my definition, requires rereading

\footnotetext{
8 With the exception of Charles Dickens, Walter Scott, and Henry Wadsworth Longfellow, the most consecrated nineteenth-century novelists and poets in Anglophone literature were only able to "live by their pen" by filling long gaps between peer-recognized literary successes with more remunerative semiliterary work ("writing for lucre," as Henry James called his periodical reviews, travel literature, political journalism, and translations). Surviving on the literary marketplace, in other words, meant for writers of high literary ambition splitting their portfolios so as to separate their laureate-oriented projects from the literary equivalent of "sawing wood" (as Herman Melville described writing White Jacket and Redburn with an eye to commercial success [(1849) 1993, p. 138]). Henry Murger's Scenes de la vie de bohème (1851) speaks of the successful bohemian's ability to live a "double life" that keeps their creative and money-making selves apart - one life for "the poet who always dreams," another for "the man who works for a living and knows how to provide daily bread" ([1851] 1988, p. 36).
} 
and intertextual connection. The practice of rereading is rooted in philological conceptions of the text as a structured whole that amounts to more than just the sum of its parts. Where leisure readers can treat a novel as a narrative sequence told in linear time (a story with a beginning, middle, and end), spatial readers want to slow down the reading pace to perceive the "architecture" of the whole, moving back and forth across the textual structure to grasp its formal simultaneities. Constructing simultaneities can be as simple as interpreting poems in terms of their stylistic arrangements (the "music" of its form) or connecting literal propositions to allegorical meanings ("the fox and scorpion are really about X"). It can also involve complex scholarly exegesis, the sort of interpretive "science" that decodes the fourfold meaning of Scripture in Biblical hermeneutics or the enigma of Kafka's The Castle in twentieth-century literary criticism.

The second element of spatial reading I want to emphasize is an attentiveness to intertextual connection generic to a historically minded philology. In contrast to the presentist immediacy that can shape the pleasures of immersive lay reading, philological hermeneutics holds that fully understanding the architecture of a text requires reconstructing its significant intertextual background, that is, the foil of preceding social and artistic conversations against which significant meanings and formal distinctiveness emerge. Spatial reading in this sense converts an apparently finite textual edifice (the published book in our hands) into a potentially infinite hypertext (the history of previous textual edifices). As book historians like to point out (Cavallo and Chartier 1999, p. 25), today's computer-accessed hypertexts were anticipated by a culture of manuscript collation epitomized in the early-modern "book wheel," a wooden contraption that could hold open a large number of volumes and spin them around to allow Renaissance humanist scholars to compare and cross-reference encyclopedic quantities of printed "sources." In more recent literary theory, this aspect of spatiality motivated normative theories of "intertextuality," inspired by late-1960s' structuralists (Julia Kristeva, Roland Barthes) who sought to shift the center of interpretation from authors or ideologies to a putative "universe of signs." More important, however, is the invention of authorized intertextual "traditions" that define a "state of the art" and to which each new literary event needs to relate itself (think of the once dominant invented tradition of "postmodernism" [e.g., Barth 1984, p. 202], which singled out a specific historical trajectory-the novel from Flaubert to Joyce, science from Newton to Einstein, philosophy from Hegel to Derrida-to claim that the realist novel had become impossible, unhistorical, false).

In contrast to event-based approaches, which treat spatial form as an objective structure that good readers must be able to reconstruct, I view spatiality in performative terms. The difference between spatial and flat reading, I argue, depends on a practical sense of relevant architectural and intertextual form. This practical sense varies not only with historical regimes of reading, but also with modes of readerly use (e.g., weak/strong, lay/professional, immersive/conceptualizing, identificatory/ distanced reading, etc.). ${ }^{9}$

\footnotetext{
${ }^{9}$ In the last two decades, literary scholarship has debated a variety of different reading regimes"paranoid" vs. "reparative reading" (Sedgwick 2003), "surface" vs. "symptomatic reading" (Best and Marcus, 2009), "suspicious" vs. "postcritical" reading (Latour 2004, Felski 2015), and "close" vs.
} 


\section{Addictive reading: an eighteenth-century debate}

The question of how one should read first emerged with the rapid mid-eighteenthcentury rise of popular leisure reading. In the early 1700 s, when literacy rates were still relatively low, the intellectual elites commended literary entertainment to the growing trade and manufacturing bourgeoisie, as a wholesome alternative to traditional weak-valued pastimes (gambling, drinking, and other vices). Joseph Addison wrote in 1712 that, unlike the "more sensual Delights" (which make us "sink" into "Negligence and Remissness"), the "Pleasures of the Imagination" could "awaken" the mental "Faculties" from "Sloth and Idleness," by "gentle Exercise" ([1712] 1988, p. 370). For Addison's generation, spatial reading seemed almost too normal to deserve further theorization. The "Pleasures of the Imagination" were thought to come naturally with politeness and literacy ${ }^{10}$ By the 1780 s, however, when with rising literacy rates and the increase of middleclass leisure, reading for pleasure had become a more widespread practice, intellectuals noticed a new way of consuming literary texts that they interpreted as a large-scale "reading addiction" (Woodmansee 1994; Erlin 2007).

The discourse of addictive reading in late-eighteenth-century Europe suggested that leisure readers (in conjunction with mercenary hacks) had fostered a corrupt literary culture that replaced spatial depth with titillating surfaces. William Wordsworth claimed, in his Preface to Lyrical Ballads (1800), that modernity diminished people's "discriminating powers" by seducing them with easily consumable sensationalist content ("frantic novels, sickly and stupid German tragedies, and deluges of idle and extravagant stories in verse"). Like other laureate-oriented poets, Wordsworth thought sensationalist surfaces were addictive because they offered readers "gross and violent stimulants" that in turn caused a "degrading thirst after outrageous stimulation" while deepening an "almost savage torpor" of mind ([1800] 2014, pp. 80-1). The German romantics at Weimar provided an anthropological account of the problem: Friedrich Schiller's Letters on Aesthetic Education (1793) argued that "raw taste" drives primitive readers to consume indiscriminately "what is new and surprising, colorful, adventurous and bizarre, violent and savage" (1992, vol. 8, p. 671). Over at Jena, the idealist philosopher Johann Gottlieb Fichte complained in 1804 that an increasing number of readers were now misusing literature as a "narcotic" that puts them in a "pleasant condition betwixt sleeping and waking," "lulls them into sweet self-forgetfulness," and undermines their incentive for active "exertion." Locked into passive consumption, Fichte said, people turned into "pure

\footnotetext{
Footnote 9 (continued)

"distant reading" (Moretti 2000)—furthering our awareness of the variability of reading practice. This debate, however, mainly focuses on how literary scholars ought to read, and concerns anxieties of academic generational succession as well as more longstanding disagreements on the role of literary criticism with regard to political activism on the one hand and scholarly knowledge production on the other (see Williams 2015; Graff 2007). My analytical distinction between spatial and non-spatial reading, by contrast, intends to explore empirical shifts in the history of reading, and the way spatiality becomes relevant to authorized distinctions between good and bad readers.

${ }^{10}$ When we take a good look at an artwork, Addison thought, its formal features "paint themselves on the Fancy, with very little Attention of Thought or Application of Mind," and we cannot but be "struck by the Symmetry" and "the Beauty of an Object" (p. 369).
} 
reader[s]" ("rein[e] Leser"): they read for the sake of immersion without connecting their reading experience to relevant intertextual knowledge or the collective project of "advancing" taste (1847, p. 89; [1804/05] 1806, p. 191).

The concept of media addiction, which connects this eighteenth-century debate with more recent media critiques, can imply weaker or stronger evaluative frames. Since the modern notion of leisure (Borsay 2006) allows us to legitimize the "uses of idleness" in purpose-rational terms-"recreation," the recharging of batteries after work-the addiction metaphor often expresses weak-valued worries about bodily and mental harm (too much trash will "blunt" our faculties) or unraveling daily routines (wasting another afternoon with cat videos, we neglect other duties). Seen in a strong frame, by contrast, leisure becomes "quality time" enabling us to find our "best selves," while media addiction corrupts our contact to hypergood-related sources of the self. In this vein, medieval theology thought destructive idleness (the sin of acedia or sloth) undermined religious connection, and Frankfurt School theorems warned that the narcotic culture industry turns reasonable citizens into sleepwalkers willingly submitting to indoctrination and exploitation. The strong-valued object of concern behind the addiction metaphor is that passive media consumption (more recently, gaming and internet addiction) may "infect" or "corrupt" the strongvalued domains of our lives.

In the literary field, the fear of "infection" first arose when eighteenth-century leisure reading reached a critical mass and forced intellectuals to rethink what they mean by the "pleasure of reading." Romantic-period writers typically distinguished their work from bone-dry scholarship and defended the more freewheeling pleasures of artistic beauty against a scholastic emphasis on conceptual propositions. ${ }^{11}$ But the rise of literary entertainment forced laureate-oriented writers and readers to separate higher from lower pleasures of reading. Wordsworth, for example, contrasts the sensualist pleasures of popular fiction ("gross and violent stimulants") from the more liberating, fulfilling, or elevating pleasures he thought his own poetry derived from "the beauty of the universe" and the "dignity of man" $(2014$, p. 87$) .{ }^{12}$

\section{Multiple spatialities: scholar-connoisseurs vs. generalist middlebrows}

The eighteenth-century discourse of addiction produced a sharp distinction between spatial and flat reading. From the perspective of high-cultural intellectuals, one could either be a normal reader, accessing the text as a living whole by penetrating

\footnotetext{
${ }^{11}$ Susan Sontag's complaint about the "philistinism of interpretation" (1966, p. 7) - when aesthetically unmusical critics reduce modern art to hermeneutic content (What can Jackson Pollock mean?)—reflects a longstanding institutional separation between literary and scholarly legitimation that began with the mid-seventeenth-century Académie française (see Viala 1985).

12 The content of "higher pleasure" is always contested and continually revised in the generational succession. Yet even writers who reject "the pleasures of beauty" tout court to celebrate, say, the more authentic pleasures of ordinary life, tend merely to switch terms. The Rousseauist claim that the smell of the earth is more extraordinary than the artificial beauty of manmade art leaves the hierarchy of higher and lower pleasure firmly in place.
} 
its architectural and intertextual depth; or a deficient reader who stays on the textual surface-level and sees not the living whole but its addictive sensual parts. This opposition obscures the relational nature of spatial form, the fact that the line between surface and depth shifts according to personal regimes of aesthetic training, including a practice-dependent gestalt-psychological sense of what counts as "sensationalist," or when exactly a form becomes titillating as opposed to, say, elevating. ${ }^{13}$ But the binary of normal vs. deficient readers, which reflects laureate-oriented strongvalued experience, came to define the most authorized economy of prestige. When the mid-nineteenth-century industrialization of print ushered in the age of mass reading, further extending the sphere of literary entertainment, this also strengthened (by indirect subsidy) a market-sheltered establishment of peer-oriented tastemakers. These mapped the binary of normal and deficient reading to a rigid social divide between "highbrow" and "lowbrow" sensibilities (Levine 1990).

The relationality of spatial reading became more visible when around 1900 the tastemaking elites themselves diversified into two formations, "highbrows" and "middlebrows." This new division was internal to the literary elites. It reflected an increasing dissociation between specialized avant-gardists and cultivated generalists. Avant-gardist cultural production tends to be focused on tight literary networks that produce high levels of specialization and reflexivity, resulting in works that require unprecedented efforts of spatial reading. A tendency toward avant-gardism already shaped the laureate position of the romantic period, where financially independent "sages" wrote for small literary coteries (before the 1820s, Wordsworth's work was recognized only by a small group of his peers while a broad literary establishment rejected him as too difficult and esoteric). But in the early 1900s the influence of avant-gardes within the reigning economy of prestige reached a critical mass, dominating the literary establishment and widening the gap between generalist and specialist concepts of fine writing. By the 1920s, the horizon of laureate practice was refocused in terms of high-modernist artifacts (Joyce, Proust, Woolf, Faulkner) for which spatial form was a more radical principle of aesthetic composition.

Joyce's Ulysses (1918-20), for example, almost completely replaces the narrative sequencing and delivery of relevant information by a loose arrangement of scattered images and references that readers need to pull together into spatial totality. To say with Joseph Frank that "Joyce cannot be read-he can only be re-read" is to point out that his spatial aesthetics forces us "to read Ulysses in exactly the same manner" as we would treat modernist poetry, "continually fitting fragments together and

\footnotetext{
13 Many of our short-hand literary-historical categories- "sensationalist fiction," the "sentimental novel," "melodrama," "kitsch"-imply that the distinction between affective overkill and subtlety or between active use and passive consumption depends on text-context structures. In actual fact these terms tend to represent the laureate view, codified in twentieth-century scholarship that naturalizes the experience of scholar-connoisseurs. As Radway's work has shown, it might not occur to readers of genre fiction romances that they are passive consumers of addictive "easy pleasures" at all ("the Smithton women made it absolutely clear that they understood themselves to be reading particular and individual authors, whose special marks of style they could recount in detail, rather than identical, factory-produced commodities" [1991, p. 11]). See also Gomart and Hennion's (1999) comparison of art and drug addicts, which stresses the active preparatory work and discipline involved in getting high on opera or chemical substances.
} 
keeping allusions in mind" until we can link them "by reflexive reference [...] to their complements" (1945, pp. 234-5). Joyce also radicalized the novel's requirements for intertextual connection. Ulysses wants a reader who is able to cope with a palimpsest of historical and mythical allusions (to Homer's Odyssey, to the history of English letters, etc.) that-as Joyce famously quipped-“will keep the professors busy for centuries arguing over what I meant" (Ellmann 1982, p. 521). The most programmatic modernist embodiment of hyperspatiality is T.S. Eliot's paradigmshaping epic poem The Waste Land (1932): Almost all of its lines are citations of previous canonical literary works, framed with deep historical references to Grail mythology and ancient fertility myths to which Eliot provides scholarly footnotes.

Eliot's canonical work as a "poet-critic" helped institutionalize a particular kind of academic spatial reader-call them scholar-connoisseurs - that came to dominate twentieth-century English Departments (Kindley 2017). Crucial to this new sensibility was a concept of "tradition" with which Eliot distinguished literary practice from both entertainment and scholarly philology. Unlike entertainment reading, literary connoisseurship requires access to the "historical sense" that compels the best authors within a single generation to write with a Western Canon in their "bones" (as Eliot put it in "Tradition and the Individual Talent"). In Eliot's spatial image, "the whole of the literature of Europe from Homer" has "a simultaneous existence and composes a simultaneous order" with which present writers need to engage if they want to create something new and worthwhile (1932, p. 4). At the same time (and in contrast to scholarly philology), Eliot thought that true engagement with tradition requires the connoisseur's powers of strong-valued discrimination. Unlike historical scholarship (the literary historians and historical linguists who dominated Anglophone literature departments until the 1930s [Graff 2007]), "criticism" in the scholar-connoisseur sense required the ability to carve out a "living tradition" from the historical past-something like "the best that has been thought and known in the world" ([1869] 1993, p. 79), in Matthew Arnold's famous phrase.

Victorians like Arnold thought that a living tradition could be accessed by welleducated gentlemen who learned how to practice "a free play of thought" (Arnold [1869] 1993, p. 151). Charles Eliot's edition of "Harvard Classics" (1909-1917), a fifty-volume collection of world literature, was predicated upon the assumption that Arnoldian self-cultivation could be gained with a daily regime of 15 min reading from a "five-foot shelf" of literary classics (Kirsch 2001). The institutionalization of academic scholar-connoisseurs increased the required amount of labor, however. Readers who wished to cultivate their minds on their own time could no longer keep up with professionalized levels of spatial depth. Generalist complaints about hyperspecialized avant-gardes already abounded in the late 1700s, but in the 1920s such complaints united a growing segment within the literary elites that became culturally visible as "middlebrow." The Book-of-the-Month-Club, the foundational US middlebrow institution, emerged in 1926 to help strong-valued amateur readers to keep in touch with the higher life of the literary nation.

As the vast literature on this topic shows (Rubin 1992; Radway 1997; Driscoll 2014; Carter 2016), discussions of "middlebrow culture" can sound more than a little defensive. Critics bristle when the language of the brows invokes denigrating markers of class, coded as human deficiency. Indeed, we can gather from Harper's 
semi-ironic charting of high, middle, and lowbrow cultures (Lynes 1949) that the social placement of taste was already well established as a popular parlor game when Bourdieu (1965) connected "l'art moyen" to a lower-middle-class habitus in France (see Carter 2016, p. 358). While the ethnographic connections between taste formation and social position are evident enough, it seems more useful to view the middlebrow as a position in literary-institutional space. This position of institutional middlebrow gained public relevance when laureate-oriented lay readers in the Arnoldian mold separated from (or were left behind by) the new formation of laureate-oriented scholar-connoisseurs who dominated modernism's economy of prestige. The defining difference between middlebrow and highbrow readers therefore concerns not social rank but institutional authority. Readers and writers have middlebrowness thrust upon them in proportion to their distance from the literary field's "Greenwich meridian" (Casanova [1999] 2004; Leypoldt 2015), the consecrating networks with the greatest weight in the debates about what counts as strong-valued reading.

The gap between professional connoisseurs and generalist lay readers increased when the postwar expansion of higher education pushed further the avant-gardization of the literary establishment that begun around 1900. At the level of readerly sensibilities, the extension of third-level education between 1960 and 1975 produced larger college-educated audiences, extending the market of serious fiction by what Loren Glass has called a "quality paperback generation" (2013, p. 28), more willing to invest time and labor in off-mainstream (specialized, experimental, "difficult") kinds of writing. At the level of authorship, the rise of the "program era" improved the situation of experimental writers by complementing the limited support networks of the modernist period with a financially more stable and prestigious academic space that made literary avant-gardism a more viable and respectable career path (McGurl 2009, p. 24). While modernist literary avant-gardes relied on a small pool of superrich patrons (like the industrial heiress Harriet Shaw Weaver, who financed Joyce's career after 1916), the rise of creative writing programs after WWII produced more substantial systems of literary patronage. Non-commercial writers profited from university-embedded social-professional networks that connected creative writing programs and English departments with editors and publishers in a transatlantic print market. And at a level of cultural authority, the education revolution shifted literature's consecrating institutions from the relatively unregulated public sphere toward an academically housed "art world" with higher degrees of gatekeeping. The most prestigious literary prizes (the Nobel, the Booker, the National Book Award) have large middlebrow audiences, but they are authorized by a peeroriented "culture of the school" (Guillory 1993, p. 38), an international network of academic scholars, credentialed writers, and publishing professionals. As literature's consecrating institutions moved closer to the postwar university, Joycean modernism entered the "museum" of canonical works, and academic scholar-connoisseurs adopted a more theory-informed and "anti-formalist" tone (epitomized by such now classic graduate school paradigms as Fredric Jameson's Neo-Marxism, Stephen Greenblatt's New Historicism, or Edward Said's Foucauldian Postcolonialism).

The relative decline of literary leisure reading since the 1950s, when film and television ended the age of mass reading that had begun in the 1850s (Griswold 
et al. 2005, p. 138; Knulst and Kraaykamp 1998), furthered, I think, the program-era academicization of strong literary value, which helped to shore up modernist spatial reading in third-level education. In today's system of prizes, institutional authority matters more than ever, but due to an increasing "gentrification" of the book, higher and lower readerly brows now indicate a diminishing social difference. This is evident in GQ magazine's 2011 update of Harper's 1949 chart (Friedman 2011): here, the social sphere of highbrow taste lists a preference simply for "books" (in contrast to the middlebrow fondness for "Coen brothers films" and the lowbrow predilection for the Spider Man franchise). Viewed from the heights of literary Greenwich, indulging in light genre fiction can still be a "guilty pleasure," but while before the 1950s the "genre fiction ghetto" embodied lower-middle-class social worlds, today it addresses roughly the same social sphere as Nobel-Prize-winning poetry. Wendy Griswold has theorized this sphere as the domain of the "reading class," the "highly educated, affluent, metropolitan" social elites (2008, p. 65) that still consume fiction on a regular basis and comprise about $15 \%$ of the general population in today's developed countries (Griswold et al. 2011, p. 23). Thus whereas older sociologies of literature could still attribute the difference between immersive and spatial reading to inequalities of class-based cultural capital, today these are more likely to correspond to different moods within a cultural elite- "whenever I finish writing a paper," the philosopher Martha Nussbaum confesses, "I read" genre fiction novels for "numbing distraction, distraction so complete that it simply blots out all stress and worry" (1990, p. 240). Ironically (and contra to the "rise of modern literature" narrative), the laureate position's high-cultural location has not changed that much since the eighteenth-century print market revolution. While large-scale leisure reading has come and gone (or moved from literary fiction to mixed digital media literacies), literature's consecrating institutions seem stronger than ever.

\section{Spatial reading in the civil sphere: from the Byron controversy to Handke's nobel prize}

We can gauge the cultural authority of the "literary-artistic field" with its strongvalued economy of prestige (Bourdieu 1996; English 2005; McGurl 2009; Sapiro 2016) from its continuing tension with the "civil sphere" in Alexander's sense. Both socio-institutional domains overlap and interpenetrate one another, yet lean toward different, often competing strong frameworks, with different notions of adequate spatiality. If the civil sacred defines what counts as good democratic behavior (or "moral decency"), the literary-artistic field connects literary excellence (or "higher form of entertainment") to high-cultural regimes of spatial reading. ${ }^{14}$

In nineteenth-century literary culture, when the peer-oriented literary-artistic field produced lower levels of institutional gatekeeping, a writer's literary authority hinged to a larger degree on his or her perceived "good character" (Ryan 2016, p. 5).

\footnotetext{
14 See Kuipers et al. (2019) on the longstanding sociological debate on the relationship of artistic excellence and morality.
} 
Inhabiting the laureate position, in other words, required a moral authority that was established through a number of proxies (credibility, gentility, respectability, admirableness, decency, or its negative foils: immorality, sensuality, atheism, profligacy, egotism, etc.) that could make or break a writer's career. By the same logic, Harriet Beecher Stowe's Uncle Tom's Cabin (1852) could be consecrated as a "Great American Novel" due to its emotionally powerful stances on democracy, abolitionism, and moral decency. Stowe's writing emerged from a bestselling new literary trend that the laureate position rejected as crude entertainment. Yet even George Eliot, as one of the most esteemed mid-century "author's authors," placed Stowe in the "highest rank of novelists" (as she put it in a review in 1856 [p. 572]) because she thought Stowe's ability to produce emotional empathy between the races was more important than questions of craft. Toward the end of the century, as the peer-oriented literary-artistic field gained in institutional weight, such verdicts came under pressure. By 1900, Uncle Tom's Cabin was reclassified as an aesthetically inferior sentimental novel, and Stowe became "the little woman who wrote the book that started this great war." Twentieth-century literary culture made it almost impossible for a writer to inhabit the laureate position with large-scale commercial entertainment. Toni Morrison's role as a public intellectual associated with black civil rights could only emerge once her work had succeeded in a literary-artistic field that rejected the comparatively thin spatiality of simple realist political "protest novels." Characteristically for the postwar literary-artistic field, Morrison succeeded in the literary prize system with Faulkner-inspired spatial prose accessible only to a small readership.

The civil sphere discourse continues to unsettle literary-artistic consecration, as we can see in the recent "societalization" of the film industry in the wake of the Weinstein effect (Alexander 2019, chap. 7). Kevin Spacey's artistic prestige was so tarnished by reports of uncivil behavior that he was cut out of a finished film and dropped from a prize-winning "quality TV" series. But then the world of film and television have lower levels of gatekeeping, comparable, I think, to the nineteenthcentury literary-artistic field. ${ }^{15}$ The Victorian "Byron controversy" might provide a useful point of comparison here. This scandal erupted in 1869, with Harriet Beecher Stowe's essay on “The True Story of Lady Byron's Life." Stowe claimed that the late Lady Byron had revealed to her in private shortly before her death that her husband had had a "secret adulterous intrigue with a blood relation," his half-sister Augusta Leigh (Ryan 2016, p. 137). Ostensibly, Stowe went public with this to defend Lady Byron against the charge (reiterated in an 1868 biography by Byron's Italian mistress, Teresa Guiccioli) that their separation was due to her "heartlessness." But Stowe made the larger point that Byron's sexual transgression rendered his poetry toxic, and she aimed to remove him from his pedestal to prevent his moral depravity

\footnotetext{
15 Since the movie industry's Oscar-mediated process of consecration is more closely tied to a market rationality than the system of literary prizes, it is more open to the financial common sense that motivated Spacey's "cancellation" as an executive act of brand repair. Moreover, mainstream film and quality TV is middlebrow in the institutional sense: it is accessible to generalist audiences who (like nineteenthcentury Arnoldians) seek "a higher kind of entertainment" that (unlike avant-garde film) does not require scholar-connoisseur skills of spatial reading. The "artworld" that produces film and TV celebrities, in other words, leaves the judgment of civility more or less to the court of opinion of the general public.
} 
from infecting less experienced, younger readers. As it happened, Stowe's attack on Byron backfired, leaving her own reputation in tatters. But the idea of "moral infection" seemed reasonable to a nineteenth-century public that believed literary works reveal the "real selves" of their authors [it is impossible, Putnam's Magazine wrote in 1853, that Dickens could have produced such memorable characters "without being himself kindred in soul to the characters he describes" (Ryan 2016, p. 111)].

With the avant-gardization of the literary establishment, debates about moral decency did not disappear, but the relevant courts of appeal now required expert skills in spatial reading. Unlike the Byron controversy, the case against Flaubert's Madame Bovary in 1857 Paris was dismissed with the help of specialists, demonstrating that the State Prosecutor had failed to grasp the novel's then unusual spatial form [unable to cope with Flaubert's virtuoso use of irony and style indirect libre, he mistook the protagonist's morality for that of the author (LaCapra 1982)]. Flaubert stands at the beginning of the modernist radicalization of textual spatiality that tends to insulate literary-artistic authority from public courts of appeal. The iconic modernisms of Richard Wagner's Ring Cycle, Martin Heidegger's philosophical system, T.S. Eliot's poetic works, or Emil Nolde's expressionist art provide instructive examples. In each of these cases, the "work" is embedded in complex figurations of consecrated form and curated spatialized "tradition" that jointly distance it from the perceived moral incivility of its biographical maker (for example, Wagner's antisemitism, Heidegger's and Nolde's collaborations with the Nazi regime, Eliot's fascist sympathies before the war).

The most recent example of the tug between literary-artistic and civil-sacred frameworks is the debate about Peter Handke's literary Nobel Prize in 2019. The controversy reveals how the disconnect between generalist and scholar-connoisseur perceptions of spatial form continues to polarize the public sphere. Unlike more generalist prizes (like the Booker or the Pulitzer, for example, whose laureates are expected to be both artistically innovative and "fast reads"), the Nobel, with its historically grown prestige, tolerates a higher degree of autonomy from mainstream leisure reading. Like many previous laureates, Handke's career has mostly depended on high-cultural peer recognition (which the German literary field rewards with access to a state-subsidized scene of high-cultural radio, television, and theater productions). He is a "difficult" author, even in the academic classroom, as his writing eludes textbook-friendly categories and does not offer representative works that could exemplify a signature style. Instead his spatial depth emerged successively over five decades, as each new work added formal and thematic registers (some avant-gardist, others essayistic or autobiographical, across a variety of genres and media), accumulating a complex literary whole. To appreciate the whole rather than some individual parts requires professional levels of bookishness rare among audiences reading on their own time.

The public sphere gave Handke a more tangible image, however, when his stances on the Yugoslavian Civil War were widely reported as justification of Serbian aggression, if not an outright denial of war crimes. These accusations hark back to an essay on behalf of Serbia for the Süddeutsche Zeitung in 1996, motivated by his critique of media reductionism. The fast-paced Western news cycles, Handke felt, were producing one-sided reports of the civil war with sensationalist images of 
"victims" and "villains." Half-Slovenian by birth, and dismayed by the breakup of Yugoslavia, Handke expressed a desire to look "behind the mirror" of medial echo chambers that he thought were biased by interests and standpoints external to Serbia (1998, p. 39). Despite its provocative headline-“Justice for Serbia [Gerechtigkeit für Serbien]"- - the essay caused no civil sphere scandal at the time (on the more local intellectual debate, see Deichmann 1996; Zülch 1996; Rieff 1997), and Handke might have left it at that. Instead he engaged in a series of public appearances that even well-meaning commentators describe as self-defeating and irresponsible (Brokoff 2014). His most "toxic" move was to speak at the funeral of Slobodan Milošević in March 2006. His short oration did not exculpate the Serbian leader or justify Serbian war atrocities (as Le Nouvel Observateur had falsely claimed [Valentini 2006] and later retracted with an apology and Handke's clarification [Editorial 2006]). But the symbolic power of Handke's presence at the funeral gave such charges undisputable performative reality in the public eye. ${ }^{16}$

With the Nobel award, the controversy gained new resonance in an international news cycle whose practical strictures allowed little patience for Handke's sense of spatial form. His writings on Yugoslavia provide no neat phrases one can reasonably pitch as "denial of Serbian atrocities," unless one quotes him out of context. This is because Handke's "justice for Serbia" frame is so embedded in qualifying reflections and mitigating turns of argument-hyper-reflexive spatial form requiring sustained hermeneutic interrogation-that generic 500-word newspaper writeups of the Nobel controversy between October and December 2019 could not even pretend to represent Handke's position without serious distortion. Even those who do isolate incriminating phrases still have to provide complex contexts to make their case coherent, which restricts the quibbling about Handke's texts to specialist intellectual debate. In the absence of pithily quotable material, serious media venues had to cover the scandal with indirect accounts that combined the briefest of summaries of Handke's reported offense with iconic photographs [Handke next to Milošević' funeral bust, footage of mass graves (Vulliamy 2019), etc.]. This practice furthered a significant narrative slippage, from reported speech ["Peter Handke, who has been accused of (...) downplaying (...) ethnic cleansing" (Mackinnon 2019)] — to reported fact ["Peter Handke-who has denied the massacre of thousands of Bosnians" (Anyuru 2019, editor's note); "a writer who denies the existence of concentration camps" (Vulliamy 2019)]. The economy of fast-readable news reporting flattened out the nuances of the affair, creating a rigid binary that left Handke in the company of convicted Holocaust deniers-even Turkey's political leader could

\footnotetext{
16 Since funeral orations conventionally imply a degree of reverence, Handke's characteristic meta-level qualifications (he said he did not go there for Milošević but for Yugoslavia, and to "feel," "see," and "remember" rather than pretend to know "the truth," etc.) did not prevent a hostile response. One month after it, in April 2006, the Paris Comédie-Française canceled a production of Handke's latest play, and in May, Düsseldorf's city governance blocked the jury decision to award him the city's prestigious Heinrich Heine Prize. During the standoff between politicians and independent jury members in Düsseldorf, Handke declined the award (in 2007 a Berlin initiative offered him an alternative Heinrich Heine Prize to protest the "political meddling" in the arts, but Handke declined this as well). Given this history of scandal, the Nobel committee surely knew what it was getting into.
} 
join the boycott of the Stockholm ceremony in the name of defending human rights (Flood 2019a).

Media with more time to delve into the intertextual background of the affair and to include a larger range of literary experts presented a more complex picture [see for example Marshall and Schuetze (2019) for the NY Times book section]. Among those more familiar with Handke (Brokoff 2014; Herwig 2010), the denialof-atrocities theory has no purchase. Here, the debate instead turns on the question of whether Handke was ethically or politically irresponsible, insensitive, naive, or at least pig-headed ["runner-up for 'International moron of the year'," according to Salman Rushdie (Cain 2019)]. But this question, too, depends on context. To the degree that the affair is removed from its literary-artistic background, and measured against a public sense of what counts as appropriate empathy and civility in the face of human suffering, newsreaders lack the context to distinguish some of Handke's speech acts from the more sinister political stances in the Balkan crisis. Political experts, similarly, accuse Handke of lacking appropriate expert knowledge [Rieff (1997) dismissed him as a "prisoner of the folkloric cliches about the place"]. Yet Handke's mixture of provocative and poetic language, and his brash treatment of inquiring journalists, owe a great deal to his literary-artistic habitus, shaped by 1960s countercultural avant-gardes that like to express their intellectual integrity with a proud disdain for public opinion and polite discourse (the Austrian writer Thomas Bernhard, and the French novelist Michel Houellebecq cultivated a similarly aggressive image). Handke's habitus resonates better with some parts of the culture of the school than others. ${ }^{17}$ But at a more fundamental level, the controversy reflects a struggle over what counts as adequate attention to the spatiality of discourse, that is, how to establish the relevant context and depth of Handke's stance. The Nobel committee, at any rate, took the scholar-connoisseur side, reiterating their trust in the political integrity of Handke's work.

\section{Conclusion}

As we have seen, Taylor's phenomenology of value teaches us that when we speak of "literature" as a singular category, we lump together two relatively distinct experiential fields, one oriented around (more or less) individualized everyday purposes, the other around practice-transcendent higher goods that compete for public authority. Looking at the different evaluative logics and socio-institutional histories of literature's weaker and stronger frameworks allows us to complicate unified-field-theory approaches that explore the "state of reading today" with single-logic inquiries

\footnotetext{
17 "When we give the award to Handke," one member of the Nobel jury, said, "we argue that the task of literature is other than to confirm and reproduce what society's central view believes is morally right" (Flood 2019b). But sensibilities about what sort of language and positions are appropriate for this differ generationally (see Sexl 2013, and Struck 2012 vs. Brokoff 2014, and Stanišić 2019) and geographically. There was near unanimous pushback against Handke's Nobel award in the US culture of the school (represented by Jennifer Egan's dismayed response for Pen America [2019]), and greater willingness to accept the media consensus.
} 
(Is literary value as such objective or relative? Is Capital-L-Literature a commodity or an autonomous singularity? Are canons and prizes elitist or democratic, important or irrelevant? Will literary reading disappear or see a "renaissance"? Etc.). The fundamental difference between weak and strong evaluative repertoires, I believe, requires scholarship to find more flexible, more practice-specific and experiencebased categories of reading. From the viewpoint of subjective attunement, the same text we appreciate as "fulfilling" in the everyday might, in our strong-valued moods, strike us as too formulaic, sentimental, too irrelevant, a "guilty pleasure." And what we perceive as mindless leisure at one moment can, in another, feel like contact with something larger (as in Schiller's "Man is never so authentically himself than when at play"). Both moods can overlap, reinforce one another, or get in each other's way; but simply to assume "homology," or "interdependency," without detailed ethnography of reading seems reductive. A similar problem, as I have tried to show, applies to single-logic narratives about the history and possible futures of reading. Since weak- and strong-valued practices tend to inhabit different experiential and socio-institutional spheres, we should beware of global rise-and-fall narratives that continue to dominate period-based literary historiography ("shift of gravity" [Watt (1957) 2000], "loss of aura" [Benjamin (1935) 1968], "return of the real" [Foster 1996], "postirony" [Konstantinou 2016], "death of the novel," [Sukenick 1969], the "fate of the literary" [Brouillette 2019b]). What I call spatial reading is therefore not an objective benchmark for best practice, or a global category of "reader-orientation" in the Constance School sense, but a framework of strong evaluation whose relevance (since its emergence in the late 1700s) depends on time and place. Accordingly, norms of spatial form do not regulate reading as such (there are large domains of weak-valued consumption where flat, immersive reading reigns supreme); but they arguably shape literature's public authorization. Like the "civil sacred," the most authorized concepts of spatial reading inscribe themselves into the materiality of the public sphere and its cultural institutions, where debates between middlebrow and scholar-connoisseur notions of good reading can be as relentless as debates about abortion. But the civil and literary-artistic sacred differ in their degree of institutional gatekeeping. If the field of cultural production functioned like a representative democracy, middlebrow audiences would outvote the experts, or feel entitled to demand equal representation (i.e., a prize system that reflects the will of "the people"). But the laureate position evolved institutional structures similar to the liberal professions, which by default restrict the right to define what counts as a higher good to credentialed forms of peer review. Indeed, peer review, almost by definition, spatializes singular events by linking them to a "state of the art"-like the imagined tradition that allows the culture of the school and its most authorized tastemakers to define the "state of the novel today" (see, for example, Zadie Smith's influential 2008 piece "Two Paths for the Novel"). Professional gatekeeping seems uncontroversial in most domains of moral and practical knowledge production (except in populist moments, people do not commonly denounce medical or scientific peer review as undemocratic). In the literary-artistic field, however, the "state-of-the-art" logic of higher good that drives the prize system and the curation of canons is at odds, not only with weak-valued experiences, but also with literature's longstanding association with freedom, emancipation, and expressive representation, notions that 
resonate well with the civil sphere. As the Handke controversy shows, the tension between these competing frameworks is not likely go away anytime soon.

Acknowledgements Open Access funding provided by Projekt DEAL. My sincere thanks to the specialissue editor and the three reviewers for their generous comments on earlier versions of this essay. Thanks also to Corinna Norrick-Rühl and the participants of our "Cultures of Reading" class at Heidelberg in the Fall 2019.

Open Access This article is licensed under a Creative Commons Attribution 4.0 International License, which permits use, sharing, adaptation, distribution and reproduction in any medium or format, as long as you give appropriate credit to the original author(s) and the source, provide a link to the Creative Commons licence, and indicate if changes were made. The images or other third party material in this article are included in the article's Creative Commons licence, unless indicated otherwise in a credit line to the material. If material is not included in the article's Creative Commons licence and your intended use is not permitted by statutory regulation or exceeds the permitted use, you will need to obtain permission directly from the copyright holder. To view a copy of this licence, visit http://creativecommons.org/licen ses/by/4.0/.

\section{References}

Addison, J. [1712 (1988)]. The Pleasures of the Imagination. In Richard Steele and Joseph Addison: Selections from The Tatler and The Spectator, ed. A. Ross, 364-406. London: Penguin.

Alexander, J.C. 2006. The Civil Sphere. Oxford: Oxford University Press.

Alexander, J.C. 2019. What Makes a Social Crisis? The Societalization of Social Problems. Cambridge: Polity.

Ammerman, N. 2013. 'Spiritual But Not Religious': Beyond Binary Choices in the Study of Religion. Journal for the Scientific Study of Religion 52 (2): 258-278.

Anyuru, J. 2019. Peter Handke's Nobel Condones Violence. The Nation, October 18, https://www.thena tion.com/article/archive/johannes-anyuru-peter-handke/. Accessed April 10, 2020.

Appadurai, A. (ed.). 1986. The Social Life of Things: Commodities in Cultural Perspective. Cambridge: Cambridge University Press.

Arnold, M. 1869 (1993). Culture and Anarchy and Other Writings. Ed. S. Collini. Cambridge: Cambridge University Press.

Aubry, T. 2018. Guilty Aesthetic Pleasures. Cambridge, MA: Harvard University Press.

Barth, J. 1984. The Friday Book. New York: Putnam's.

Bellah, R., and H. Joas (eds.). 2012. The Axial Age and Its Consequences. Cambridge, MA: Harvard University Press.

Bellah, R.N., et al. (eds.). 1985. (2007) Habits of the Heart. Berkeley: University of California Press.

Benjamin, W. 1968. Illuminations: Essays and Reflections. New York: Harcourt Brace.

Berger, P. 2014. The Many Altars of Modernity: Toward a Paradigm for Religion in a Pluralist Age. Boston: de Gruyter.

Best, S., and S. Marcus. 2009. Surface Reading: An Introduction. Representations 108 (1): 1-21.

Borsay, P. 2006. A History of Leisure: The British Experience Since 1500. London: Palgrave.

Brokoff, J. 2014. 'Ich wäre gern noch viel skandalöser': Peter Handkes Texte zum Jugoslawien-Krieg im Spannungsfeld von Medien, Politik und Poesie. In Peter Handke: Stationen, Orte, Positionen, ed. A. Kinder, 17-37. Berlin: De Gruyter.

Brouillette, S. 2015. UNESCO and the World-Literary System in Crisis. Amodern, https://amodern.net/ article/unesco-brouillette/. Accessed April 4, 2020.

Brouillette, S. 2019a. Romance Work. Theory \& Event 22 (2): 451-464.

Brouillette, S. 2019b. UNESCO and the Fate of the Literary. Stanford: Stanford University Press.

Bourdieu, P. 1965. Un art moyen: essai sur les usages sociaux de la photographie. Paris: Minuit.

Bourdieu, P. 1996. The Rules of Art: Genesis and Structure of the Literary Field. Stanford: Stanford University Press. 
Cain, S. 2019. 'A troubling choice': Authors Criticise Peter Handke's Controversial Nobel Win. The Guardian, October 11, https://www.theguardian.com/books/2019/oct/10/troubling-choice-authorscriticise-peter-handke-controversial-nobel-win. Accessed June 19, 2020.

Carter, D. 2016. Middlebrow Book Culture. In Routledge International Handbook of the Sociology of Art and Culture, ed. L. Hanquinet and M. Savage, 349-369. London: Routledge.

Casanova, P. 1999. (2004) The World Republic of Letters. Cambridge: Harvard University Press.

Cavallo, G., and R. Chartier. 1999. A History of Reading in the West. Cambridge: Polity.

Collini, S. 2019. The Nostalgic Imagination: History in English Criticism. Oxford: Oxford University Press.

Connolly, W.E. 2000. Why I Am Not a Secularist. Minneapolis: University of Minnesota Press.

Deichmann, T. (ed.). 1996. Noch einmal für Yugoslawien: Peter Handke. Frankfurt: Suhrkamp.

Driscoll, B. 2014. The New Literary Middlebrow: Tastemakers and Reading in the Twenty-First Century. London: Palgrave.

Editorial. 2006. Sur 1' 'affaire Handke'. Nouvel Observateur, May 4, https://www.nouvelobs.com/cultu re/20060503.OBS6399/sur-1-affaire-handke.html. Accessed April 10, 2020.

Eisenstadt, S.N. 1982. The Axial Age: The Emergence of Transcendental Visions and the Rise of Clerics. European Journal of Sociology 23 (2): 294-314.

Eliot, G. 1856. Belles Lettres. Westminster Review 66 (130): 566-582.

Eliot, T.S. 1932. Selected Essays, 1917-1932. New York: Harcourt, Brace and Company.

Ellmann, R. 1982. James Joyce. Oxford: Oxford University Press.

Emre, M. 2017. Paraliterary: The Making of Bad Readers in Postwar America. Chicago: University of Chicago Press.

English, J. 2005. The Economy of Prestige: Prizes, Awards, and the Circulation of Cultural Value. Cambridge, MA: Harvard University Press.

Erlin, M. 2007. Useless Subjects: Reading and Consumer Culture in Eighteenth-Century Germany. The German Quarterly 80 (2): 145-164.

Felski, R. 2015. The Limits of Critique. Chicago: University of Chicago Press.

Felski, R. 2020. Hooked: Art and Attachment. Chicago: University of Chicago Press.

Fichte, J.G. 1804/05 (1806). Die Grundzüge des gegenwärtigen Zeitalters. Berlin: Realschulbuchhandlung.

Fichte, J.G. 1847. The Characteristics of the Present Age. Trans. William Smith. London: Chapman.

Flood, A. 2019a. Protests grow as Peter Handke receives Nobel medal in Sweden. The Guardian, December 10, https://www.theguardian.com/books/2019/dec/10/protests-grow-ahead-of-nobel-prize -ceremony-for-peter-handke. Accessed April 10, 2020.

Flood, A. 2019b. Swedish Academy defends Peter Handke's controversial Nobel win. The Guardian, October 21, https://www.theguardian.com/books/2019/oct/21/swedish-academy-defends-peter -handkes-controversial-nobel-win. Accessed April 12, 2020.

Foster, H. 1996. The Return of the Real. Boston: MIT Press.

Frank, J. 1945. Spatial Form in Modern Literature: An Essay in Two Parts. The Sewanee Review 53 (2): 221-240.

Franssen, T., and G. Kuipers. 2015. Sociology of Literature and Publishing in the Early 21st Century: Away From the Centre. Cultural Sociology 9 (3): 291-295.

Friedman, D. 2011. Middlebrow: The Taste That Dare Not Speak Its Name. GQ, June 10, https://www. gq.com/story/middlebrow-culture. Accessed January 4, 2020.

Glass, L. 2013. Counterculture Colophon: Grove Press, the Evergreen Review, and the Incorporation of the Avant-Garde. Stanford: Stanford University Press.

Gomart, E., and A. Hennion. 1999. A Sociology of Attachment: Music, Amateurs, Drug Users. The Sociological Review 47 (1): 220-274.

Graff, G. 2007. Professing Literature: An Institutional History. Chicago: University of Chicago Press.

Griffin, D. 2014. Authorship in the Long Eighteenth Century. Newark: University of New Delaware Press.

Griswold, W. 2008. Regionalism and the Reading Class. Chicago: University of Chicago Press.

Griswold, W., T. McDonnell, and N. Wright. 2005. Reading and the Reading Class in the Twenty-First Century. Annual Review of Sociology 31: 127-141.

Griswold, W., E. Lenaghan, and M. Naffziger. 2011. Readers as Audiences. In The Handbook of Media Audiences, ed. V. Nightingale, 19-40. Oxford: Wiley-Blackwell.

Guillory, J. 1993. Cultural Capital: The Problem of Literary Canon Formation. Chicago: University of Chicago Press.

Guillory, J. 2000. The Ethical Practice of Modernity. In The Turn to Ethics, ed. M. Garber et al., 29-46. London: Routledge. 
Handke, P. 1998. Gerechtigkeit für Serbien: Eine winterliche Reise zu den Flüssen Donau, Sawe, Morawa und Drina. Süddeutsche Zeitung, Januar 5/6 and 13/14, 1996. Reprinted in Abschied des Träumers, Winterliche Reise, Sommerlicher Nachtrag. Frankfurt: Suhrkamp, 2019

Hartman, A. 2015. "A War for the Soul of America”: A History of the Culture Wars. Chicago: University of Chicago Press.

Helgerson, R. 1983. Self-Crowned Laureates: Spenser, Jonson, Milton, and the Literary System. Berkeley: University of California Press.

Hennion, A. 2015. The Passion for Music: A Sociology of Mediation. Surrey: Ashgate.

Herwig, M. 2010. Meister der Dämmerung: Peter Handke. Eine Biographie. Frankfurt: DVA.

Highmore, B. 2017. Cultural Feelings: Mood, Mediation and Cultural Politics. New York: Routledge.

Jameson, F. 1981. The Political Unconscious: Narrative as a Social Symbolic Act. Ithaca: Cornell University Press.

Joas, H. 2000. The Genesis of Values. Chicago: University of Chicago Press.

Joas, H. 2013. The Sacredness of the Person: A New Genealogy of Human Rights. Washington, DC: University of Georgetown Press.

Karpik, L. 2010. Valuing the Unique: The Economics of Singularities. Princeton: Princeton University Press.

Kindley, E. 2017. Poet-Critics and the Administration of Culture. Cambridge, MA: Harvard University Press.

Kirsch, A. 2001. The 'Five-foot Shelf' Reconsidered. Harvard Magazine. https://harvardmagazine .com/2001/11/the-five-foot-shelf-reco.html. Accessed January 3, 2020.

Knulst, W., and G. Kraaykamp. 1998. Trends in Leisure Reading: Forty Years of Research. Poetics 26: 21-41.

Konstantinou, L. 2016. Cool Characters: Irony and American Fiction. Cambridge, MA: Harvard University Press.

Kuipers, G., T. Franssen, and S. Holla. 2019. Clouded judgments? Aesthetics, Morality and Everyday Life in Early-21st-Century Culture. European Journal of Cultural Studies 22 (4): 383-398.

Kuper, A. 1999. Culture: The Anthropological Account. Cambridge, MA: Harvard University Press.

LaCapra, D. 1982. Madame Bovary on Trial. Ithaca: Cornell University Press.

Latour, B. 2004. Why Has Critique Run out of Steam? Critical Inquiry 30: 225-248.

Levine, L. 1990. Highbrow/Lowbrow: The Emergence of Cultural Hierarchy in America. Cambridge, MA: Harvard University Press.

Leypoldt, G. 2015. Shifting Meridians: US Authorship in World-Literary Space. American Literary History 27 (4): 768-787.

Leypoldt, G. 2016. Degrees of Public Relevance: Walter Scott and Toni Morrison. Modern Language Quarterly. 77 (3): 369-393.

Leypoldt, G. 2017. Knausgaard in America: Literary Prestige and Charismatic Trust. Critical Quarterly. 59 (3): 55-69.

Lynes, R. 1949. Highbrow, Lowbrow, Middlebrow. Harper's Magazine, February 19-28.

Mackinnon, A. (2019) 'This Is a Stain on the Nobel Prize Organization.' Foreign Policy, December 9, https://foreignpolicy.com/2019/12/09/this-is-a-stain-on-the-nobel-prize-organization/. Accessed May 12, 2020.

Marshall, A. and Schuetze, C. (2019) Genius, Genocide Denier or Both? New York Times, December 10, https://www.nytimes.com/2019/12/10/books/peter-handke-nobel-prize.html. Accessed April 10, 2020.

McGurl, M. 2009. The Program Era: Postwar Fiction and the Rise of Creative Writing. Cambridge, MA: Harvard University Press.

Melville, H. 1849. (1991) Letter to Lemuel Shaw, [6 October]. In Correspondence, ed. L. Horth, 137139. Evanston: Northwestern University Press.

Moretti, F. 2000. Conjectures on World Literature. New Left Review 1: 1-68.

Murger, H. 1851. (1988) Scènes de la vie de bohème. Paris: Gallimard.

Nussbaum, M. 1990. Essays on Philosophy and Literature. Oxford: Oxford University Press.

Partridge, C. 2006. The Re-Enchantment of the West: Alternative Spiritualities, Sacralization, Popular Culture and Occulture. London: T. \& T. Clark Publishers.

Pen America, Statement: Deep Regret Over the Choice of Peter Handke for the 2019 Nobel Prize in Literature, https://pen.org/press-release/statement-nobel-prize-for-literature-2019/. Accessed April $10,2020$. 
Radway, J. 1991. Reading the Romance: Women, Patriarchy, and Popular Literature, 2nd ed. Chapel Hill, NC: University of North Carolina Press.

Radway, J. 1997. A Feeling for Books: The Book-of-the-Month Club, Literary Taste, and Middle-Class Desire. Chapel Hill, NC: University of North Carolina Press.

Rieff, D. 1997. Short Book, Long Apology: A Journey To The Rivers: Justice for Serbia. Los Angeles Times, January 12, https://www.latimes.com/archives/la-xpm-1997-01-12-bk-17740-story.html. Accessed April 10, 2020.

Rilke, R.M. 1908 (1995). Archaic Torso of Apollo [Archaïscher Torso Apollos]. Ahead of All Parting: Selected Poetry and Prose of Rainer Maria Rilke, transl. Stephen Mitchell. New York: Modern Library, pp. 67-68.

Rorty, R. 1982. Consequences of Pragmatism. New York: Harvester.

Rosa, H. 2019. Resonance: A Sociology of Our Relationship to the World. Cambridge: Polity.

Rubin, J.S. 1992. The Making of Middlebrow Culture. Chapel Hill, NC: University of North Carolina Press.

Ryan, S.M. 2016. The Moral Economies of American Authorship: Reputation, Scandal, and the Nineteenth-Century Literary Marketplace. New York: Oxford University Press.

Sapiro, G. 2016. The Metamorphosis of Modes of Consecration in the Literary Field: Academies, Literary Prizes, Festivals. Poetics 59: 5-19.

Sapiro, G. 2019. The Writing Profession in France: Between Symbolic and Professional Recognition. French Cultural Studies 30 (2): 105-120.

Sapiro, G. 2019b. Rethinking the Concept of Autonomy for the Sociology of Symbolic Goods. Biens symboliques / Symbolic Goods 4, June 27, https://revue.biens-symboliques.net/334. Accessed September 2019.

Schiller, F. 1992. Werke und Briefe. Ed. Otto Dann et al. Frankfurt: DKV.

Sedgwick, E.K. 2003. Paranoid Reading and Reparative Reading, or, You're So Paranoid, You Probably Think This Essay is About You. In: Touching Feeling. Durham, NC: Duke University Press, pp. $123-152$.

Sexl, M. 2013. Poesie als Medienkritik. Die Jugoslawien-Kriege im Werk Peter Handkes. Handkeonline, March 4, https://handkeonline.onb.ac.at/forschung/pdf/sexl-2013.pdf.

Sloterdijk, P. 2013. You Must Change Your Life. Cambridge: Polity.

Smith, B.H. 1988. Contingencies of Value: Alternative Perspectives for Critical Theory. Cambridge, MA: Harvard University Press.

Smith, Z. (2008) Two Paths for the Novel. NYRB, November 20. https://www.nybooks.com/artic les/2008/11/20/two-paths-for-the-novel/. Accessed September 29, 2019.

Sollors, W. 1986. Beyond Ethnicity: Consent and Descent in American Culture. Oxford: Oxford University Press.

Sontag, S. 1966. Against Interpretation and Other Essays. New York: Farrar, Straus \& Giroux.

Spoerhase, C. 2018. Rankings: A Pre-History. New Left Review 114 (6): 99-112.

Stanišić, S. 2019. Geschichte ist uns egal. Sollen andere Generationen verarbeiten. Wir belohnen die Adjektive. Twitter, October 10, 6.09 pm, https://twitter.com/sasa_s/status/1182327323800068096. Accessed April 6, 2020.

Struck, L. 2012. Peter Handke und Jugoslawien: Die dritte Erregungswelle. Handkeonline, June 17. https ://handkeonline.onb.ac.at/forschung/pdf/struck-2012.pdf. Accessed April 12, 2020.

Sukenick, R. 1969. The Death of the Novel and Other Stories. New York: Dial Press.

Taylor, C. 1985. What is Human Agency? Human Agency and Language, 15-44. Cambridge: Cambridge University Press.

Taylor, C. 1989. Sources of the Self: The Making of Modern Identity. Cambridge, MA: Harvard University Press.

Taylor, C. 2007. A Secular Age. Cambridge, MA: Harvard University Press.

Taylor, C. 2011. Dilemmas and Connections. Cambridge, MA: Harvard University Press.

Tompkins, J. 1985. Sensational Designs: The Cultural Work of American Fiction, 1790-1860. Oxford: Oxford University Press.

Tylor, E. 1871. (1903) Primitive Culture: Researches into the Development of Mythology, Philosophy, Religion, Language, Art, and Custom. London: Murray.

Valentini, R. 2006. Peter Handke à Pozarevac. Le Nouvel Observateur 2161, April 6, p. 102, https:// www.nouvelobs.com/culture/20060504.OBS6468/peter-handke-a-pozarevac.html. Accessed April $10,2020$. 
Valéry, P. 1937 (2016). Leçon inaugurale du cours de poétique du Collège de France. In: Euvres. Ed. Michel Jarrety. 3 vols. Paris: Le Livre de Poche. Vol. 3, pp. 952-74.

Viala, A. 1985. Naissance de l'écrivain: Sociologie de la littérature à l'âge classique. Paris: Minuit.

Vulliamy, E. 2019. Peter Handke's Nobel Prize Dishonours the Victims of Genocide. The Guardian, Oct 12, https://www.theguardian.com/commentisfree/2019/oct/12/a-nobel-prize-that-dishonours-thevictims-of-genocide-peter-handke. Accessed April 10, 2020.

Watt, I. 1957. (2000) The Rise of the Novel: Studies in Defoe, Richardson, and Fielding. London: Pimlico.

Weber, M. 1972. Wirtschaft und Gesellschaft: Grundriss der verstehenden Soziologie. Tübingen: Mohr-Siebeck.

Williams, J. 2015. The New Modesty in Literary Criticism. Chronicle of Higher Education, January 5, https://www.chronicle.com/article/The-New-Modesty-in-Literary/150993. Accessed April 3, 2020.

Woodhead, L., and P. Heelas. 2000. Religion in Modern Times. London: Blackwell.

Woodmansee, M. 1994. The Author, Art, and the Market: Rereading the History of Aesthetics. New York: Columbia University Press.

Wordsworth, W. 2014. Wordsworth's Poetry and Prose. Ed. Nicholas Halmi. New York: Norton.

Wuthnow, R. 1950s. After Heaven: Spirituality in America Since the 1950s. Berkeley: University of California Press.

Zelizer, V. 2011. Economic Lives: How Culture Shapes the Economy. Princeton: Princeton University Press.

Zola, È. 1879 (1893). The Influence of Money in Literature [1880] In: The Experimental Novel and Other Essays. New York: Cassell, pp. 161-206.

Zülch, T. (ed.). 1996. Die Angst des Dichters vor der Wirklichkeit: 16 Antworten auf Peter Handkes Winterreise nach Serbien. Göttingen: Steidl.

Publisher's Note Springer Nature remains neutral with regard to jurisdictional claims in published maps and institutional affiliations.

Günter Leypoldt is a Professor of American Literature and Culture at the University of Heidelberg, the author of Cultural Authority in the Age of Whitman: A Transatlantic Perspective (2009), and editor of Intellectual Authority and Literary Culture in the US, 1790-1900 (2013) and Reading Practices (2015). His current research centers on the nexus of authority and trust and the history of literary institutions. 